\title{
A Restriction Map of Naphthalene Catabolic Plasmid pWW60-1 and the Location of Some of Its Catabolic Genes
}

\author{
By PATRICIA A. CANE AND PETER A. WILLIAMS* \\ Department of Biochemistry \& Soil Science, University College of North Wales, Bangor, \\ Gwynedd LL57 2UW, UK
}

(Received 4 December 1985; revised 22 May 1986)

\begin{abstract}
A restriction map for the $87 \mathrm{kbp}$ IncP9 naphthalene catabolic plasmid pW $60-1$ is presented. Transposon mutants were obtained using direct Tn5 insertion or using an indirect method involving the intermediate formation of unstable cointegrates between RP4 and pWW60-1. Insertions which affected expression of the early enzymes of the pathway (naphthalene to salicylate) were separated from inserts which affected expression of salicylate hydroxylase (nahG) or catechol 2,3-oxygenase $(n a h H)$. nahABC were cloned on a contiguous region of the plasmid on either a $6.9 \mathrm{kbp}$ HindIII fragment (HE) or a $5.7 \mathrm{kbp}$ XhoI fragment (XD). nahGH were cloned on a region situated about $30 \mathrm{kbp}$ from nahABC on an Xhol fragment (XC), but $n a h H$ was only expressed on the corresponding but smaller $X h o I$ fragments from two derivative plasmids of $\mathrm{pWW60-1}$ with a deletion in that region. The detailed restriction map of $n a h H$ shows no similarities with the restriction maps of the genes for catechol 2,3-oxygenases from TOL plasmids, although the cloned gene did hybridize with genes for catechol 2,3-oxygenase from two different TOL plasmids. The organization of the catabolic genes on $\mathrm{pWW} 60-1$ suggests a separation into two operons as also described for the naphthalene catabolic plasmid NAH7 (alternatively called pIG7), but the relative directions of their transcription differs from that in NAH7
\end{abstract}

\section{INTRODUCTION}

In Pseudomonas strains which have been isolated by selective enrichment on naphthalene as sole carbon source, the genes coding for the breakdown of naphthalene are usually carried on plasmids (Dunn \& Gunsalus, 1973; Boronin et al., 1977, 1980; Cane \& Williams, 1982). Pseudomonas sp. NCIB9816, also called Pseudomonas $\mathbf{P}_{\mathrm{G}}$ (Williams et al., 1975), is the strain in which the main features of the naphthalene catabolic pathway were first elucidated by Davies \& Evans (1964). They showed that naphthalene was converted to salicylate along with the release of pyruvate: catechol formed from salicylate was then catabolized to central metabolites by the meta pathway, involving cleavage of the ring by catechol 2,3-oxygenase (C23O) (Fig. 1) (Davies \& Evans, 1964; Murray et al., 1972). Subsequently, there was some disagreement in the literature concerning the route of catechol metabolism when it was reported that the ortho or $\beta$ ketoadipate pathway was used (Fig. 1) (Barnsley, 1976), and it became apparent that a number of variants of NCIB9816 were in circulation (Barnsley, 1976; Cane \& Williams, 1982).

A partial explanation for these variants was obtained by a study of the genetics of naphthalene catabolism by NCIB9816. This strain was found to contain two plasmids, one of which carried the naphthalene genes (Cane \& Williams, 1982; Connors \& Barnsley, 1982). This latter plasmid (87kbp; IncP9) was transferred into a plasmid-free Pseudomonas putida strain PaW340 to give a single transconjugant, PaW701 (Cane \& Williams, 1982). The plasmid in PaW701, pWW60-1, was responsible for the conversion of naphthalene only as far as catechol, which was then further

Abbreviations: $\mathrm{C} 23 \mathrm{O}$, catechol 2,3-oxygenase; $\mathrm{SH}$, salicylate hydroxylase. 

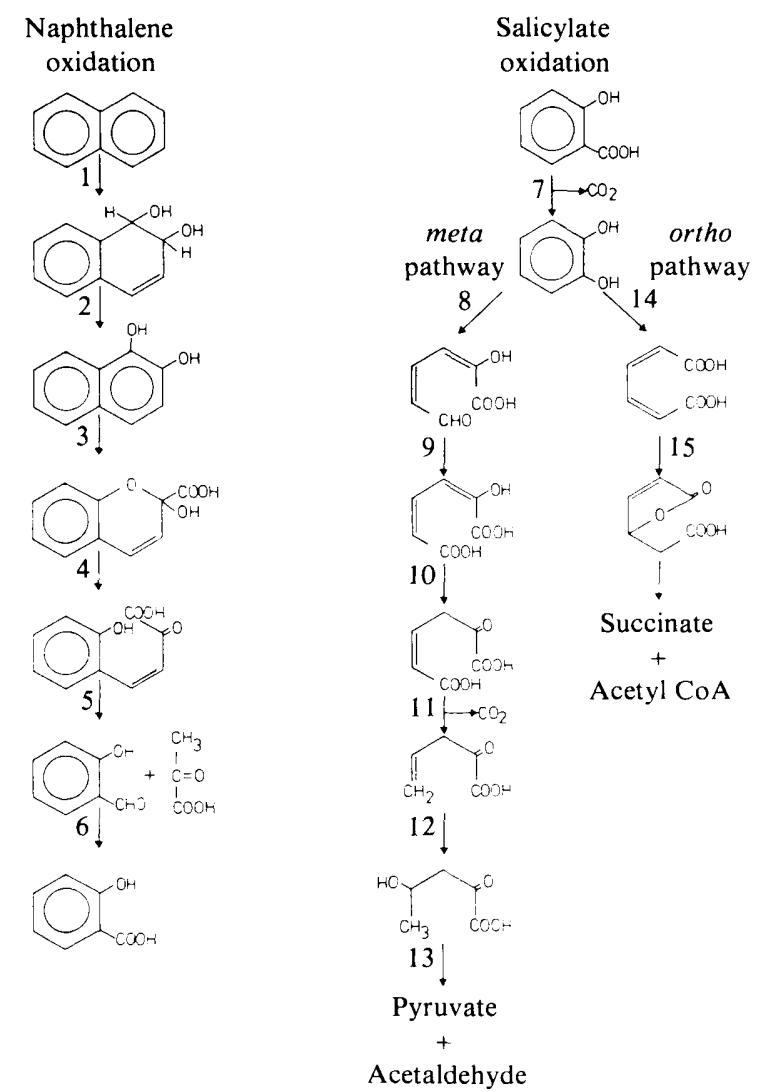

Fig. 1. Pathway for the catabolism of naphthalene. Enzymes (genes) shown are: 1, naphthalene dioxygenase (nahA);2, naphthalene cis-dihydrodiol dehydrogenase (nahB); 3, 1,2-dihydroxynaphthalene dioxygenase $(n a h C) ; 4,2$-hydroxychromene-2-carboxylate isomerase (nahD); 5, 2-hydroxybenzalpyruvate aldolase $(n a h E) ; 6$, salicylaldehyde dehydrogenase $(n a h F) ; 7$, salicylate hydroxylase $(n a h G) ; 8$, catechol 2,3-oxygenase $(n a h H) ; 9,2$-hydroxymuconic semialdehyde dehydrogenase (nahI); 10, 4oxalocrotonate tautomerase (nahJ); 11, 4-oxalocrotonate decarboxylase (nahK); 12, 2-oxo-4-pentenoate hydratase $(n a h L) ; 13,2$-oxo-4-hydroxypentanoate aldolase (nahM); 14, catechol 1,2-oxygenase $($ cat $A) ; 15$, cis, cis-muconate lactonizing enzyme (catB).

metabolized by the enzymes of the chromosomally-coded ortho pathway. However, it was possible to select spontaneous mutants from $\mathrm{PaW} 701$ cultures which used a plasmid-coded meta pathway. Examination of the plasmids in some of these mutants showed a deletion of 1.2 to $1.5 \mathrm{kbp}$ between genes for salicylate hydroxylase $(\mathrm{SH})$ and $\mathrm{C} 23 \mathrm{O}$ which apparently allowed expression of previously silent meta pathway genes.

This paper describes further studies on pWW60-1. A restriction endonuclease map of the plasmid has been derived and some of the structural and regulatory genes have been cloned and mapped.

\section{METHODS}

Bacterial strains and plasmids. Details of all relevant parent bacterial strains and their plasmid complements are listed in Table 1. In Table 2, a list is presented of all the derivative strains into whose plasmids has been inserted a transposon or other transposable DNA : all these are in a PaW85 or PaW340 background. Table 3 is a list of all the plasmids carrying cloned fragments from pWW60-1 or its derivatives; these are in Escherichia coli PM191.

Preparation of plasmid $D N A$. Large plasmids $(>40 \mathrm{kbp})$ were extracted by the method of Wheatcroft \& Williams (1981). Small plasmids were screened according to Holmes \& Quigley (1981), and prepared in quantity by $\mathrm{CsCl}$ density gradient centrifugation of cleared lysates (Guerry et al., 1973). 
Table 1. Bacterial strains used in this study

\begin{tabular}{|c|c|c|}
\hline Strain & Plasmid & Relevant phenotype* \\
\hline \multicolumn{3}{|l|}{ Pseudomonas } \\
\hline NCIB9816 & pWW60, pWW61 & $\mathrm{Nah}^{+} 2 \mathrm{MeNah}^{+} \mathrm{Sal}^{-} 4 \mathrm{MeSal}^{-}$ \\
\hline AC34 & RP4 & $\mathrm{Ade}^{-} \mathrm{Ap}^{r} \mathrm{Km}^{r} \mathrm{Tc}^{r}$ \\
\hline PaW85 & - & $\mathrm{Nah}^{-} \mathrm{Sal}^{-} \mathrm{Str}^{\mathrm{r}}$ \\
\hline PaW 130 & - & Rif \\
\hline PaW340 & - & $\mathrm{Nah}^{-} \mathrm{Sal}^{-} \mathrm{Trp}^{-} \mathrm{Str}^{\mathrm{r}}$ \\
\hline PaW701 & pWW60-1 & $\mathrm{Nah}^{+} 2 \mathrm{MeNah}^{-} \mathrm{Sal}^{+} 4 \mathrm{MeSal}^{-}$ \\
\hline PaW705 & pWW60-14 & \\
\hline PaW707 & pWW60-2 & $\mathrm{Nah}^{+} 2 \mathrm{MeNah}^{+} \mathrm{Sal}^{+} 4 \mathrm{MeSal}^{+}$ \\
\hline PaW719 & pWW60-22 & \\
\hline PaW740 & pWW60-1, RP4 & $\begin{array}{l}\mathrm{Nah}^{+} 2 \mathrm{MeNah}^{-} \mathrm{Sal}^{+} 4 \mathrm{MeSal}^{-} \\
\mathrm{Trp}^{-} \operatorname{Str}^{r} \mathrm{Ap}^{r} \mathrm{Km}^{\mathrm{r}} \mathrm{Tc}^{r}\end{array}$ \\
\hline PaW741 & pWW60-40 & $\mathrm{Nah}^{-\mathrm{Sal}^{+}} 4 \mathrm{MeSal}^{+} \mathrm{Trp}^{-} \mathrm{Str}^{r}$ \\
\hline $\mathrm{PaW} 742$ & pWW60-40, RP4 & $\begin{array}{l}\mathrm{Nah}^{-} 2 \mathrm{MeNah}^{-} \mathrm{Sal}^{+} 4 \mathrm{MeSal}^{+} \\
\text {Trp }^{-} \mathrm{Str}^{r} \mathrm{Ap}^{r} \mathrm{Km}^{r} \mathrm{Tc}^{r}\end{array}$ \\
\hline \multirow{6}{*}{$\begin{array}{l}\text { E. coli } \\
\text { WG3110 } \\
\text { pM191 }\end{array}$} & & \\
\hline & pLG221 & $\mathrm{Km}^{\mathrm{r}}$ \\
\hline & - & $\mathrm{Thr}^{-} \mathrm{Leu}^{-} \mathrm{Thi}^{-} \mathrm{RecA}^{-}$ \\
\hline & pK T230 & $\mathrm{Km}^{\mathrm{r}} \mathrm{Str}^{\mathrm{r}}$ \\
\hline & pBR322 & $T c^{r} A p^{r}$ \\
\hline & pNJ5000 & $T c^{r}$ \\
\hline
\end{tabular}

Notes and references

Wild-type

Franklin \& Williams (1980)

Bayley et al. (1977)

Keil et al. (1985b)

Cane \& Williams (1982)

Cane \& Williams (1982)

Spontaneous deletion mutants of PaW701; Cane \& Williams (1982)

Conjugation AC34 $\times$ PaW701; this paper

Spontaneous $\operatorname{Tn}(\mathrm{TOL})$ insertion mutant of PaW707; this paper Conjugation AC34 $\times$ PaW741; this paper

F.C.H. Franklin; unpublished rec $A$ derivative of $\mathrm{C} 600$; Bachman (1972) Bagdasarian et al. (1981) Bolivar et al. (1977) Derivative of RP4; Grinter (1983)

${ }^{*} \mathrm{Nah}^{+}, 2 \mathrm{MeNah}^{+}, \mathrm{Sal}^{+}$and $4 \mathrm{MeSal}^{+}$denote ability to grow on naphthalene, 2-methylnaphthalene, salicylate and 4-methylsalicylate, respectively, as sole carbon sources. $\mathrm{Ade}^{-}, \mathrm{Trp}^{-}$, $\mathrm{Thr}^{-}$, $\mathrm{Leu}^{-}$and $\mathrm{Thi}^{-}$denote requirements for adenine, tryptophan, threonine, leucine and thiamin respectively. $\operatorname{Rif}^{r}, \mathrm{Str}^{\mathrm{r}}, \mathrm{Km}^{\mathrm{r}}, \mathrm{Ap}^{\mathrm{r}}$ and $\mathrm{Tc}^{\mathrm{r}}$ denote resistance to rifampicin, streptomycin, kanamycin, ampicillin and tetracycline respectively.

Restriction endonuclease digestion. All digestions and subsequent electrophoreses were done as described previously (Wheatcroft \& Williams, 1981).

Extraction of DNA from agarose gels. This was done by the method of McDonnell et al. (1977).

Conjugation. Samples $(10 \mu \mathrm{l})$ of overnight broth cultures of donor and recipient strains were pipetted onto sterile Millipore filters on nutrient agar plates and incubated for 15-24 h. The filters were then washed in $1 \mathrm{ml} 100 \mathrm{~mm}$ phosphate buffer (pH 7.5) and the washings spread, with dilutions as necessary, on agar plates of appropriate selective media.

Formation of RP4::pWW60-1 cointegrate plasmids. Donor strain Pseudomonas aeruginosa AC34(RP4) was mated with PaW701 and PaW741 selecting for transconjugants resistant to kanamycin $\left(100 \mu \mathrm{g} \mathrm{ml}^{-1}\right)$. PaW740 and PaW742 were maintained as typical transconjugants from each mating. These were then mated with plasmidfree strain PaW85, selecting for simultaneous transfer of ability to grow on salicylate and resistance to kanamycin. Transconjugants were subsequently screened for loss of ability to grow on naphthalene (for strains derived from PaW701) or on 4-methylsalicylate (for strains derived from PaW741).

Insertion of Tn5 into naphthalene plasmids. E. coli WG 3110 carrying the Tn 5 suicide vector plasmid pLG 221 was mated with $\mathrm{PaW} 705$ as recipient selecting for transconjugants able to grow on benzoate in the presence of $100 \mu \mathrm{g}$ kanamycin $\mathrm{ml}^{-1}$. The plasmid DNA of transconjugants was screened for insertion of $\mathrm{Tn} 5$, but none was found, even though there was no trace of pLG221: it was therefore assumed that $\operatorname{Tn} 5$ had inserted into the chromosome. One of the strains produced was then used as donor in matings with PaW85, selecting for transfer of kanamycin resistance, and relying on the kanamycin resistance gene being mobilized only if it had transposed into the plasmid. This occurred at only a very low frequency.

Cloning experiments. DNA from the vector plasmid (pKT230 or pBR322) and from the appropriate naphthalene plasmid were mixed and digested with the relevant restriction enzyme according to the suppliers protocol. Sodium acetate (pH 5.6) was added to a final concentration of $200 \mathrm{~mm}$ and the DNA precipitated with ethanol. After two washes with $70 \%(\mathrm{v} / \mathrm{v})$ aqueous ethanol, the DNA was resuspended in ligation buffer and incubated with T4 ligase as specified by the supplier for $20 \mathrm{~h}$ at $20^{\circ} \mathrm{C}$. The ligated DNA was transformed into $E$. coli pM191 by standard procedures (Cohen et al., 1972).

Detection of clones expressing naphthalene catabolic activities. Cultures of E. coli expressing naphthalene dioxygenase (nahA) turned blue when grown in well-aerated culture in nutrient broth due to the production 
of indigo (Ensley et al., 1983). When gene products of both nahA and nahB (naphthalene cis-dihydrodiol dehydrogenase) were present in the same strain, a brown colour developed around colonies grown on nutrient agar in the presence of naphthalene due to the auto-oxidation of accumulated 1,2-dihydroxynaphthalene. nahC (for 1,2dihydroxynaphthalene dioxygenase) could be detected by spraying colonies with freshly prepared $100 \mathrm{mM}-3$ methylcatechol (but not catechol), which was rapidly converted to a bright yellow ring fission product. When $2.5 \mathrm{mM}$-salicylate was incorporated into isosensitest agar plates, the presence of SH (nahG gene product) alone produced a black colour in colonies, caused by catechol accumulation and auto-oxidation, whilst the joint presence of $\mathrm{SH}$ and $\mathrm{C} 23 \mathrm{O}(\mathrm{nahH})$ resulted in the production of bright yellow 2-hydroxymuconic semialdehyde. By spraying colonies with $100 \mathrm{mM}$-catechol, $\mathrm{nahH}^{+}$clones could be detected by their almost immediate conversion to a yellow colour.

Mobilization of recombinant plasmids into $P$. putida. Recombinant plasmids derived from pKT230 were mobilized into plasmid-free PaW130 by an RP4 derivative, pNJ5000 (Grinter, 1983), as previously described (Keil et al., 1985b).

Southern blotting. Southern blots (Southern, 1975) and hybridizations were done as previously described (Keil \& Williams, 1985).

Enzyme assays. SH and C23O were assayed as previously described (Cane \& Williams, 1982).

\section{RESULTS}

\section{Restriction map of $p W W 60-1$}

The sizes of the restriction fragments of pWW60-1 produced by digestion with HindIII and $X$ hoI have been published previously (Cane \& Williams, 1982). BamHI digestion gave six fragments: A, 23-25 kbp; B, 22-24 kbp; C, $19 \mathrm{kbp}$; D, 10.1 kbp; E, 5.1 kbp; F, 3.3 kbp. The map of the plasmid with respect to these enzymes is shown in Fig. 2: it is complete for the

Table 2. Strains carrying plasmids with transposon insertions

\section{Strain}

PaW711

PaW741

PaW743

PaW744

PaW745

PaW746

PaW927

PaW901

PaW902

PaW903

PaW907

PaW908

PaW909

PaW911, PaW912, PaW913

PaW914, PaW917

PaW918

PaW919, PaW920, PaW921

$\mathrm{PaW} 922$

PaW924

PaW728, PaW729

PaW730

PaW923

PaW926

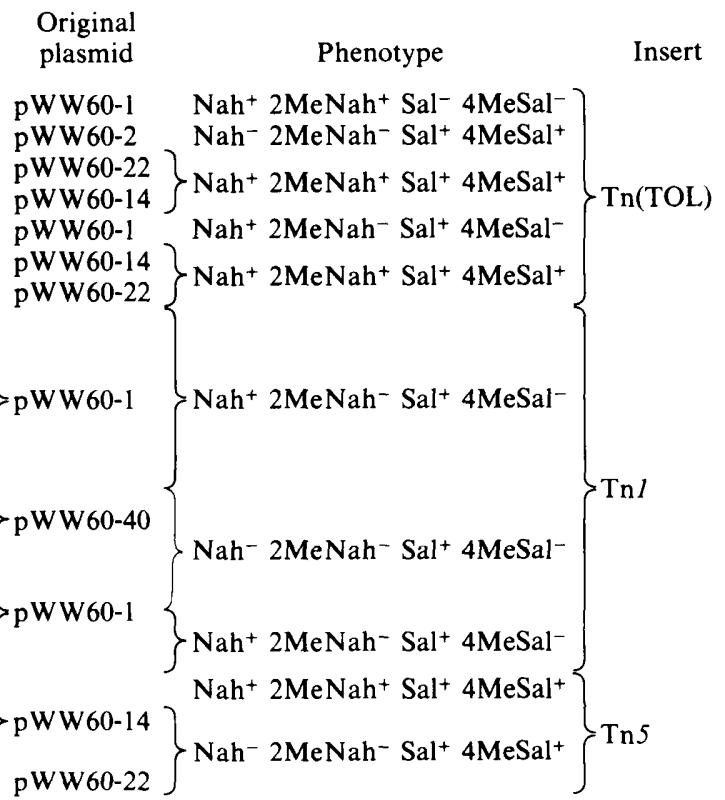

\section{Restriction fragments carrying the insert ${ }^{*}$}

* The first letter refers to the restriction enzyme (B, BamHI; H, HindIII; X, XhoI), the second to the fragment (Fig. 2).

$+\mathrm{XC}^{\prime \prime \prime}$ is a $4.8 \mathrm{kbp}$ fragment formed by a spontaneous deletion in $\mathrm{XC}$ found in parental pWW60-40; it is indistinguishable from $\mathrm{XC}^{\prime}$ from $\mathrm{pWW} 60-14$.

$\ddagger$ a refers to one or more small unidentified HindIII fragments $(<1 \mathrm{kbp})$. 
Table 3. Recombinant plasmids carrying cloned $p W W 60-1$ genes

\begin{tabular}{|c|c|c|c|}
\hline Plasmid & NAH plasmid & Genes detected & Notes \\
\hline $\begin{array}{l}\text { pWW60-3002 } \\
\text { pWW60-3017 }\end{array}$ & pWW60-1 & $n a h A, n a h B$ & $\begin{array}{l}\text { HindIII fragment } \mathrm{HE} \text { in pKT } 230 \\
\text { As for } \mathrm{pWW} 60-3002 \text {, but with } \mathrm{HE} \text { in } \\
\text { reversed orientation }\end{array}$ \\
\hline pWW60-3021 & & None & BamHI fragment BD in pBR322 \\
\hline pWW60-3006 & & nahC & XhoI fragment XD in pKT230 \\
\hline pWW60-3008 & pWW60-22 & None & $\begin{array}{l}\text { As for } \mathrm{pWW} 60-3006 \text {, but with } \mathrm{XD} \text { in } \\
\text { reversed orientation }\end{array}$ \\
\hline pWW60-3001 & & & HindIII fragment $\mathrm{HH}$ in pKT230 \\
\hline pWW60-3003 & pWW60-1 & $n a h G$ & $X$ hol fragment $\mathrm{XC}$ in pK T230 \\
\hline pWW60-3004 & pWW60-14 & $n a h G, n a h H$ & Xhol fragment $\mathrm{XC}^{\prime}$ in $\mathrm{pKT} 230$ \\
\hline pWW60-3005 & & nahG, nahH, nahR & $X$ hoI fragment $\mathrm{XC}^{\prime \prime}$ in $\mathrm{pKT} 230$ \\
\hline pWW60-3010* & & $n a h G$ & $\begin{array}{l}\text { XhoI-HindIII fragment of pWW60-3005 } \\
\text { obtained by HindIII digestion and } \\
\text { religation }\end{array}$ \\
\hline pWW60-3011* & & None & $\begin{array}{l}\text { XhoI-SmaI fragment of } \mathrm{pWW} 60-3005 \\
\text { obtained by SmaI digestion and religation }\end{array}$ \\
\hline pWW60-3012* & pWW60-22 & & $\begin{array}{l}\text { SmaI-XhoI fragment of pWW60-3005 } \\
\text { obtained by SmaI digestion and ligation } \\
\text { into new pKT } 230\end{array}$ \\
\hline pWW60-3013* & & nahH & $\begin{array}{l}\text { KpnI-XhoI fragment of pWW60-3005 } \\
\text { obtained by partial KpnI digestion and } \\
\text { religation }\end{array}$ \\
\hline pWW60-3014* & & None & $\begin{array}{l}\text { KpnI-XhoI fragment of } \mathrm{pWW} 60-3005 \\
\text { obtained by KpnI digestion and religation }\end{array}$ \\
\hline pWW60-3016* & & $n a h G$ & $\begin{array}{l}\text { Pst } \mathrm{I}-\text { Pst I fragment of } \mathrm{pWW} 60-3005 \text { obtained } \\
\text { by Pst I digestion and ligation into pBR } 322\end{array}$ \\
\hline
\end{tabular}

BamHI fragments, and essentially complete for the other enzymes, apart from the order of some fragments, particularly those internal to BamHI-B, and the location of some smaller fragments $(<1 \mathrm{kbp})$. The map was derived from a variety of different experimental results which included the examination of spontaneous deletion plasmids and plasmids with inserts (Table 2), and the multiple restriction digestion of cloned fragments (Table 3 ), and of bands extracted from agarose gels.

\section{Insertion mutants}

Transposition of Tn5 into pWW60-14 or pWW60-22 occurred at very low frequency and only five such insertion strains were isolated (Table 2). However, experiments to form RP4:: pWW60-1 or RP4::pWW60-40 cointegrates proved a much more successful, although indirect, way of obtaining insertion mutants. In the matings selecting for cotransfer of both plasmid phenotypes, cointegrates were formed in which the entire RP4 and naphthalene plasmids were linked; however these cointegrates were very unstable and dissociated, during subculture of strains, to give a complete naphthalene plasmid that contained a $5 \mathrm{kbp}$ insert with an identical restriction pattern to $\mathrm{Tn} l$, even though there was no selection for ampicillin resistance. This formation of cointegrates apparently involving $\mathrm{Tn} l$ appears similar to that reported by McCormick et al. (1981).

In addition, a number of spontaneous insertions in pWW60-1 and its derivatives were found: $\mathrm{PaW} 741$ (Table 1) is a typical example of a spontaneous insertion mutant of this type. In these strains, the DNA inserted was about $17 \mathrm{kbp}$ in size and had the characteristic digestion pattern previously found for the inserts which enabled some mutants of PaW701 to grow on 2methylnaphthalene (Cane \& Williams, 1982). In the original mutants it was shown by Southern blotting that this insert was derived from the TOL plasmid pWW0, of which the host strain PaW340 is a cured derivative. It appears that this element is present in the chromosome of PaW340 (Meulien \& Broda, 1982) and acts as a transposon, able to insert spontaneously into plasmids resident in PaW340 (Williams et al., 1983). This has occurred into other catabolic 


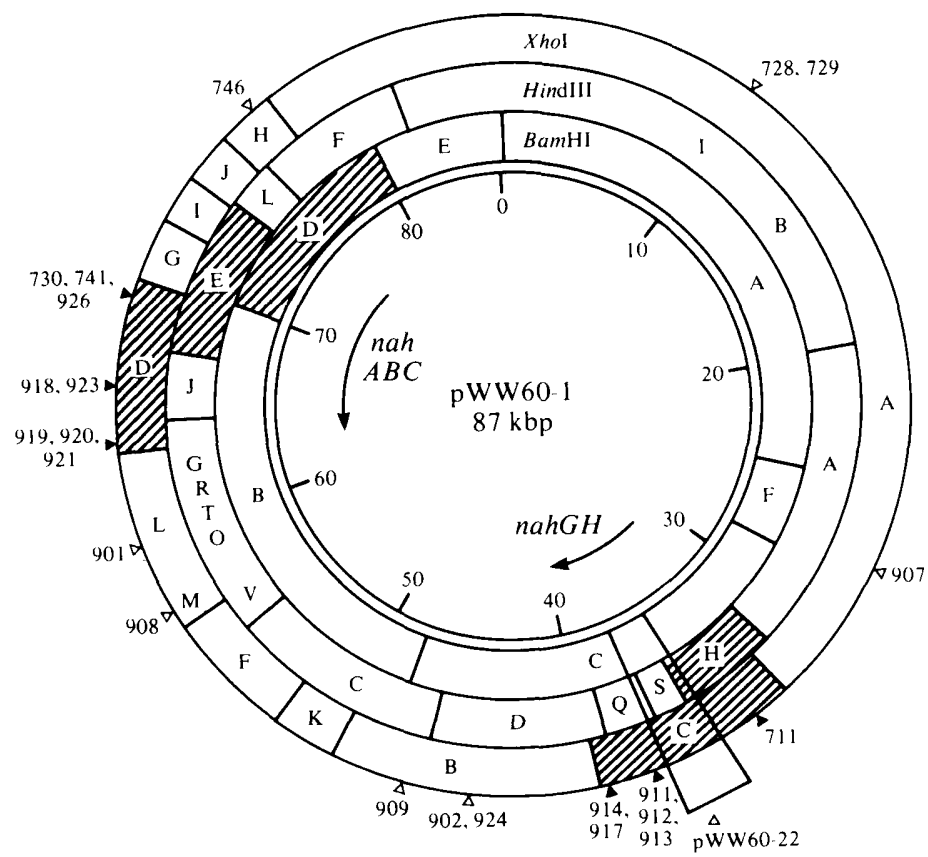

Fig. 2. Restriction endonuclease map of pWW60-1. $\Delta$, Insertions which have a catabolic effect; $\triangle$, insertions without a catabolic effect, with the proviso that these insertions were made in plasmids which already have the natural insertion between nahG and nahH. The number of the insertion refers to the strain number given in Table 2. The deletion which has occurred in $\mathrm{pWW} 60-22$ and which removes the natural block to expression of the meta pathway genes (nahHIJKLM) is shown. Arrows show the direction of transcription of the genes. The major fragments cloned in this paper are hatched.

plasmids resident in PaW340 in our laboratory and we believe that the insert may well be a transposon, although we have not been able to test its independence of $\operatorname{rec} A$ function: we propose that it be called $\mathrm{Tn}(\mathrm{TOL})$ as a temporary nomenclature until definitive experiments are done.

Insertions into the catabolic genes can be monitored by testing the host strains for growth on naphthalene, salicylate and 4-methylsalicylate. Growth on naphthalene, albeit poorly, can occur even with the pathway blocked after salicylaidehyde, since pyruvate released from oxidation of the first ring can serve as a growth substrate. Salicylate, but not 4-methylsalicylate, can be metabolized via the chromosomal $\beta$-ketoadipate if the plasmid meta pathway is blocked below $\mathrm{SH}$. Several classes of structural gene mutants are therefore possible: (i) with the pathway blocked between $n a h A$ and $n a h F$, strains would be unable to grow on naphthalene but able to grow on salicylate or 4-methylsalicylate; (ii) with the pathway blocked in $n a h G$, strains would be able to grow poorly on naphthalene but not on salicylate; (iii) with the pathway blocked in $n a h H$, strains would be able to grow on naphthalene and salicylate but not on their methylated derivatives; (iv) with the pathway blocked between $n a h I$ and $n a h M$, strains would be expected to grow only poorly or not at all on naphthalene and salicylate due to accumulation of potentially toxic meta fission products. There are also possible regulatory mutants with different phenotypes depending on how the pathway is regulated.

All mutants of class (i) had insertions in fragments XD, BB, and HE or $\mathrm{HJ}$ or in a small unmapped HindIII fragment of $<1 \mathrm{kbp}$ (Table 2, Fig. 2). All class (ii) mutants had inserts in fragments $\mathrm{XC}, \mathrm{BC}$ and $\mathrm{HH}$ confirming the location of $n a h G$ in the region previously described (Cane \& Williams, 1982). The mutants obtained which were of class (iii) all lacked C23O activity, as shown by the catechol spray test, and therefore had inserts directly in $n a h H$ or in a gene necessary for $n a h H$ expression, and all mapped in fragments XC, BC and HD or HQ. No mutants of class (iv) were obtained. 


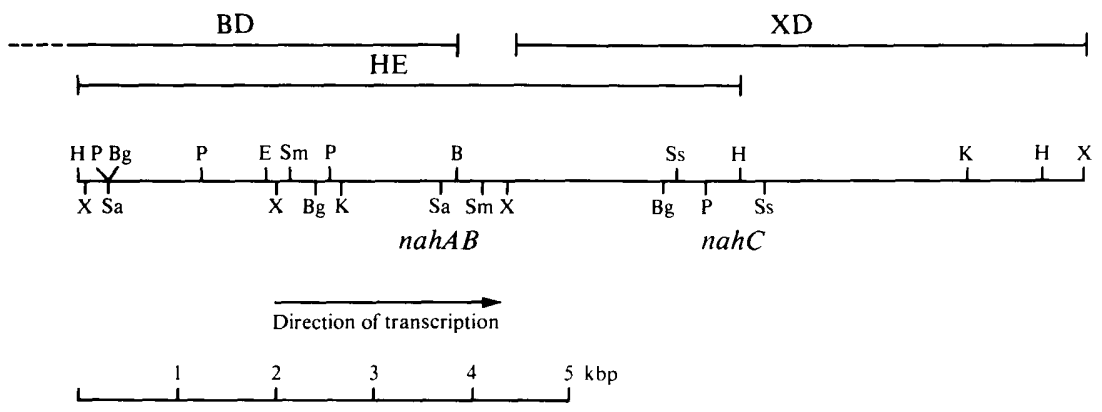

Fig. 3. Restriction map of the region overlapping HindIII fragment E (HE), BamHI fragment D (BD) and $\mathrm{XhoI}$ fragment D (XD) of pWW60-1. Abbreviations used for restriction endonucleases are: B, BamHI; Bg, BglII; E, EcoRI; H, HindIII; K, KpnI; P, PstI; Sa, SalI; Sm, SmaI; Ss, SstI; X, XhoI.

Between the insertions of class (i) and classes (ii) and (iii), there was a region of 15-20 kbp into which several inserts were found which had no apparent effect on the catabolic phenotype (PaW901, 902, 908, 909). However, since these strains were derived from PaW701, which has a cryptic meta pathway and uses the chromosomal ortho pathway for catechol metabolism, it is possible that this region, or part of it, encodes the meta pathway genes nahI to nahM (Fig. 1).

\section{Cloning of nah $A B C$}

A list of recombinant plasmids carrying cloned fragments is shown in Table 3. Two fragments, HE and XD, shown by transposition mutagenesis to be involved in the conversion of naphthalene to salicylate were cloned into $E$. coli on pKT230. Recombinant plasmid pWW603002 (HE) expressed $n a h A$ and $n a h B$, while pWW60-3006 (XD) expressed nahC, presumably under the influence of the kanamycin promoter of pKT230. When HE was inserted into pKT230 in the opposite orientation (pWW60-3017), nahA continued to be expressed, as shown by the production of indigo, although qualitatively this appeared to be at a lower level than with

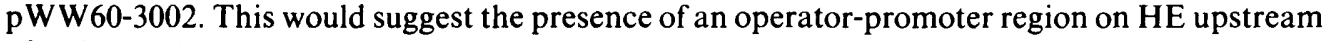
of nahAB which allows its weak expression. In contrast, pWW60-3008, carrying XD in the opposite orientation, no longer expressed nahC.

The BamHI fragment BD, which overlapped HE (Fig. 2), was also cloned into pBR322, but the $E$. coli host showed no accumulation of indigo: this indicates that the BamHI site between $\mathrm{BD}$ and $\mathrm{BB}$ lies within or upstream of nahAB.

The restriction endonuclease map of the HE/XD region of pWW60-1 is shown in Fig. 3.

\section{Cloning of $n a h G H$}

Recombinant plasmids carrying XC (pWW60-3003) and HH (pWW60-3001) from pWW60-1 expressed SH (nahG) but not $\mathrm{C} 23 \mathrm{O}(n a h H)$. However, the plasmids in derivatives of $\mathrm{PaW} 701$, namely PaW705 and 719, selected for their ability to grow on 2-methylnaphthalene, have deletions of 1.2 and $1.5 \mathrm{kbp}$ respectively in $\mathrm{XC}\left(\mathrm{XC}^{\prime}, \mathrm{XC}^{\prime \prime}\right)$; when these fragments were cloned into pK T230, in pWW60-3004 and pWW60-3005, both SH and C23O were expressed. A map of $\mathrm{XC}$ and its deleted derivatives is shown in Fig. 4. The recombinant plasmid pWW60-3005 was the subject of more detailed analysis by fine mapping and subcloning and these results are also shown in Fig. 4.

pWW60-3016 (Table 3) expressed SH but not C23O indicating that the start of nahG is downstream of the PstI site at the coordinate of $1 \mathrm{kbp}$ (Fig. 4). pWW60-3013 does not express SH indicating that the KpnI site at $1.8 \mathrm{kbp}$ is within the gene. Neither pWW60-3011 nor pWW60-3012 expressed SH, and we have shown that transposon insertion either side of the SmaI site inactivated nahG (data not shown), also indicating that this site is within the gene. However, $n a h G$ cannot extend more than $0.2 \mathrm{kbp}$ downstream of this SmaI site since the HindIII 


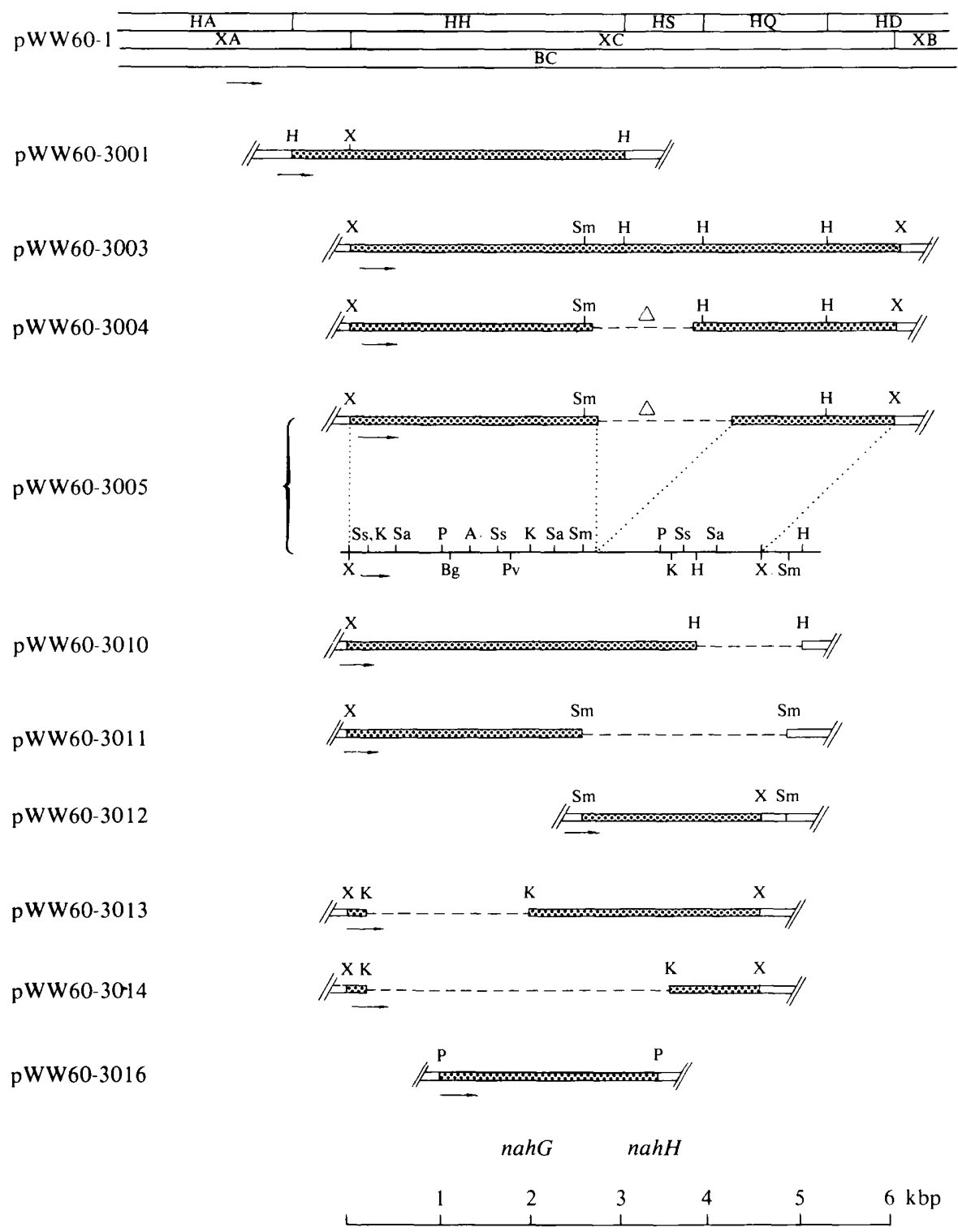

Fig. 4. Restriction map of the region overlapping HindIII fragment $\mathrm{H}(\mathrm{HH})$ and $X$ hoI fragment $\mathrm{C}(\mathrm{XC})$ of pWW60-1, together with the clones and subclones derived from this region of $\mathrm{pWW60-1}$ and from the same region of the deleted derivative plasmids pWW60-22 and pWW60-14, which express meta pathway genes. Abbreviations for restriction endonucleases are given in Fig. 3, except for: A, AvaI ; Pv, PvuII. Arrows show the direction of transcription from the vector promoters. Cloned catabolic plasmid DNA in the recombinant plasmids; --.--, deletions produced in the subcloning; $\triangle$, deletions in the parental plasmids.

fragment carried by pWW60-3001, which does express $\mathrm{SH}$, goes no further than this. Thus nahG must lie between points at $1 \mathrm{kbp}$ and $2.8 \mathrm{kbp}$ on the parent fragment.

Subclone pWW60-3012 expressed $\mathrm{C} 23 \mathrm{O}$ indicating that $n a h H$ is downstream of nahG. The starting point of this gene must be downstream of the boundary of the deletion in pWW60-3005 in which it is also expressed (Fig. 4). Subclones pWW60-3010 and pWW60-3014 did not express nahH indicating that there are HindIII and KpnI sites within the gene. The restriction 
(a)

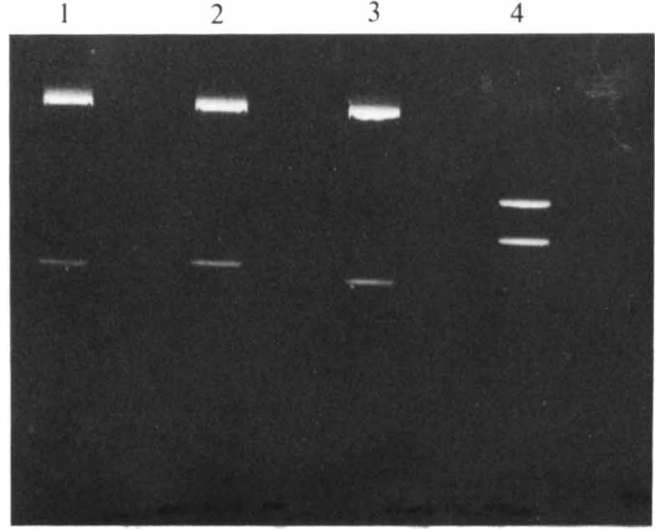

(b)

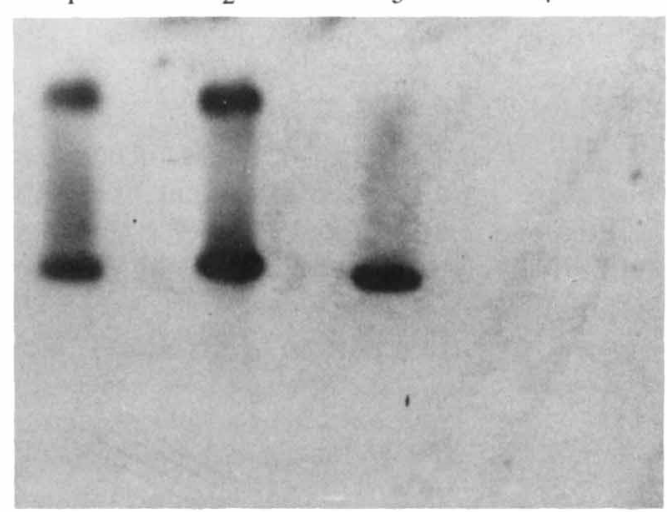

Fig. 5. Hybridization analysis of cloned fragments carrying catechol 2,3-oxygenase genes. (a) Agarose gel of restriction digests of plasmids and $(b)$ an autoradiogram of same gel after Southern blotting and hybridization to the SmaI fragment of pWW60-3012, which was extracted from agarose gels prior to being radiolabelled with ${ }^{32} \mathrm{P}$ by nick-translation. Track 1 , control containing plasmid $\mathrm{pWW60-3012}$ (Fig. 4) cut with SmaI. The upper band is the vector, pKT230, and the lower band is the $2 \cdot 3 \mathrm{kbp} S \mathrm{maI}$ fragment carrying nahH. Track 2, pWW0-3004 cut with $X h o$ I. This plasmid contains the $2 \cdot 3 \mathrm{kbp} X h o \mathrm{I}$ fragment I (XI), from TOL plasmid pWW0, which carries the $x y l E$ gene (for catechol 2,3-oxygenase). The vector is pKT230 (upper band), which, as in track 1, hybridizes against the probe. Track 3, pWW15-3151 cut with $X h o l$. This plasmid is a recombinant between pKT230 and the $2 \cdot 1 \mathrm{kbp} X \mathrm{hoI}$ fragment $\mathrm{h}(\mathrm{Xh})$ from TOL plasmid $\mathrm{pWW} 15$. The insert carries the gene for C23OI, previously shown to be homologous with $x y l E$ from pWW0 (Track 2) (Keil et al., 1985a). Track 4, pWW15-3171 cut with $H$ indIII and $\mathrm{XbaI}$. This plasmid is a recombinant between vector pUC12 (lower band) and a $3.4 \mathrm{kbp}$ $X$ XaI-HindIII insert, from TOL plasmid pWW15 (upper band), which carries the gene for C23OII. This second gene has been shown to share no apparent homology with the C23OI gene from $\mathrm{pWW} 15$ or with $x y l E$ from pWW0 (Keil et al., 1985a). It should be noted that the fragment used as probe contains about $0.25 \mathrm{kbp}$ of pKT230 (see Fig. 4), which might account for the relatively weaker hybridization of the vector band in tracks 1 and 2 .

endonuclease sites in the vicinity of this $\mathrm{C} 23 \mathrm{O}$ gene showed no similarities with those of the C230 genes from TOL plasmids (Keil et al., 1985a; L. K. Chatfield \& P. A. Williams, unpublished results). However, when pWW60-3012 was used as a probe in Southern blots against recombinant plasmids carrying either the $\mathrm{C} 23 \mathrm{O}$ gene $(x y l E)$ from archetypal TOL plasmids pWW0 or the homologous gene for C23OI from TOL plasmid pWW15 (Keil et al., $1985 a$ ), strong hybridization was seen (Fig. 5); there was no hybridization with the cloned gene for the second $\mathrm{C} 23 \mathrm{O}$ (C23OII) from $\mathrm{pWW} 15$. In addition, there was no apparent hybridization with the pWW60-1 XD fragment carrying the nahC gene for 1,2-dihydroxynaphthalene dioxygenase, an enzyme functionally similar to $\mathrm{C} 23 \mathrm{O}$.

\section{Cloning of a possible regulatory gene}

pWW60-3005 was mobilized into P. putida PaW130 to give strain PaW936 for enzyme analysis (see Methods). Addition of 5 mm-anthranilate, a gratuitous inducer of both upper and lower pathways (Shamsuzzaman \& Barnsley, 1974), to a nutrient broth culture of PaW936 resulted in an increase in $\mathrm{C} 23 \mathrm{O}$ activity from $1 \mu \mathrm{mol} \mathrm{min}^{-1}(\mathrm{mg} \text { protein })^{-1}$ in uninduced cells to $26 \mu \mathrm{mol} \mathrm{min}^{-1}(\mathrm{mg} \text { protein })^{-1}$ in induced cells. This suggests the presence of a positive regulator gene on this fragment, similar to $n a h R$ of pIG7 (Grund \& Gunsalus, 1983; Yen \& Gunsalus, 1985).

\section{DISCUSSION}

The naphthalene catabolic plasmid pWW60-1 has a number of interesting features. The first of these is that there appears to be a sequence of DNA between $n a h G$ and $n a h H$ which 
terminates transcription after salicylate hydroxylase, thus channelling the catechol formed through the chromosomal $\beta$-ketoadipate pathway (Cane \& Williams, 1982). However, selection for growth on 2-methylnaphthalene or 4-methylsalicylate, which are converted by $\mathrm{SH}$ to methylcatechols that can only be processed by the meta pathway, can result in a loss of a minimum of $1.2 \mathrm{kbp}$ between $n a h G$ and $n a h H$, which permits complete transcription of the meta pathway. If such an apparently innocuous procedure as growth on 2-methylnaphthalene can result, through a deletion of a segment of DNA, in a complete change in the route by which naphthalene is assimilated, then it is not surprising that different laboratories have obtained contradictory results with clones of the same strain. One variant of NCIB9816, Pseudomonas $P_{G}$, has an inducible SH but a constitutive $\mathrm{C} 23 \mathrm{O}$ (Barnsley, 1976); the plasmid in this strain has an identical restriction pattern to $\mathrm{pWW60-1}$. However, the original parent strain of Pseudomonas $P_{G}$, from which all the other strains have ultimately been derived but which appears to be no longer extant, apparently had a fully inducible meta pathway (Catterall $e$ et al., 1971), similar to that shown by PaW705 and 719 (Cane \& Williams, 1982). These results suggest that the original wild-type may have had separate and independent regulation of nahG and the meta pathway genes, unlike the situation in NAH7 where the entire pathway from SH onwards is within one operon (Yen \& Gunsalus, 1982). Point mutations could then switch off the meta pathway, as in PaW701, or make it constitutive, as in Pseudomonas $\mathbf{P}_{\mathrm{G}}$, or, after a large deletion, allow the meta pathway to come under the same control as SH, as in PaW705 and 719.

One feature of this plasmid is that the upper and lower operons appear to be transcribed in opposite directions towards each other. This is in contrast to the situation reported for NAH7, where the two operons are transcribed in the same direction from the upper operon through to the lower operon with the regulatory gene $n a h R$ in between, although the nahR-like gene of pWW60-1 also appears to lie immediately before $n a h G$. We have no evidence as to whether the nah genes on the two plasmids share any homology but, even if they do, the different relative orientations of the two operons exclude the possibility of a simple recombinant event leading to the acquisition of essentially the same piece of DNA by the two plasmids. However, the separation of the operons on both plasmids and of the two operons on the TOL plasmid pWW0 (Worsey et al., 1978; Nakazawa et al., 1980) suggests an attractive hypothesis for their evolution. It is possible that the pathway was formed by the combination on a single replicon of preevolved metabolic 'modules', one responsible for enzymes for converting naphthalene to salicylate, one for $\mathrm{SH}$, and a third element encoding the meta pathway enzymes. This would account for the apparent homology between the C23O genes of pWW60-1 and TOL plasmids, indicating that TOL and pWW60-1 may share related meta pathway DNA, and would also suggest that the presence of a separate operon for SH may be necessary in the initial evolution of a naphthalene catabolic plasmid. Such a hypothesis of related meta pathways would obviously require subsequent refinement to take account of some differences in the enzymology such as, for example, the absence of a hydrolytic branch (2-hydroxymuconic semialdehyde hydrolase) from the naphthalene meta pathway (Catterall et al., 1971). However, conclusive evidence on the evolution of these long catabolic pathways and their plasmid carriers will only come from a detailed comparative investigation of their molecular biology.

We would like to thank both Mrs L. Gibb and Dr S. Assinder for their technical assistance in parts of this work. This work was funded in part by SERC grant no. GR/D 17557.

\section{REFERENCES}

BaChman, B. J. (1972). Pedigrees of some mutant strains of E. coli K12. Bacteriological Reviews 30, 525-557.

Bagdasarian, N., Franklin, F. C. H., Lurz, R., Ruckert, B., Bagdasarian, N. N. \& Timmis, K. N. (1981). Specific purpose vectors. II. Broad host range high copy number RSF 1010-derived vectors, and a host : vector system for gene cloning. Gene 16, 237247.

Barnsley, E. A. (1976). Role and regulation of the ortho and meta pathways of catechol metabolism in pseudomonads metabolising naphthalene and salicylate. Journal of Bacteriology 125, 404408.

Bayley, S. A., Duggleby, C. J., Worsey, M. J., Williams, P. A., Hardy, K. G. \& Broda, P. (1977). Two modes of loss of the TOL function from Pseudomonas putida mt-2. Molecular and General Genetics 154, 203-204.

Bolivar, F., Rodgriguez, R. L., Green, P. J., Belach, H. C., Heynecker, H. L., Boyer, H. W., Crosa, J. J. \& Falkow, S. (1977). Construction and 
characterisation of new cloning vehicles. II. A multipurpose cloning system. Gene 2, 95-113.

Boronin, A. M., Kochetov, V. V., StaRovoitov, I. I. \& SKR YABIN, G. K. (1977). Plasmids pBS2 and pBS3, controlling the oxidation of naphthalene in bacteria of the genus Pseudomonas. Doklady Academii nauk SSSR 237, 1205-1208.

Boronin, A. M., Kochetov, V. V. \& Skryabin, G. K. (1980). Incompatibility groups of naphthalene degradative plasmids in Pseudomonas. FEMS Microbiology Letters 7, 249-252.

Cane, P. A. \& Williams, P. A. (1982). The plasmidcoded metabolism of naphthalene and 2-methylnaphthalene in Pseudomonas strains: phenotypic changes correlated with structural modification of the plasmid pWW60-1 Journal of General Microbiology 128, 2281-2290.

Catterall, F. A., Sala-Trepat, J. M. \& Williams, P. A. (1971). The coexistence of pathways for the metabolism of 2-hydroxymuconic semialdehyde in a naphthalene-grown pseudomonad. Biochemical and Biophysical Research Communications 43, 463-469

Cohen, S. N., Chang, A. C. Y. \& Hsu, C. L. (1972). Non-chromosomal antibiotic resistance in bacteria: genetic transformation of Escherichia coli by $\mathrm{R}$ factor DNA. Proceedings of the National Academy of Sciences of the United States of America 69, 21102114.

Connors, M. A. \& Barnsley, E. A. (1982). Naphthalene plasmids in Pseudomonads. Journal of Bacteriology 149, 1096-1101.

Davies, J. I. \& Evans, W. C. (1964). Oxidative metabolism of naphthalene by soil pseudomonads. Biochemical Journal 91, 251-261.

DunN, N. W. \& Gunsalus, I. C. (1973). Transmissible plasmid coding early enzymes of naphthalene oxidation in Pseudomonas putida. Journal of Bacteriology 114, 974-979.

Ensley, B. D., Ratzkin, B. J., Osseund, T. D., Simon, M. J., WACkeTt, L. P. \& Gibson, D. T. (1983). Expression of naphthalene oxidation genes in Escherichia coli results in the biosynthesis of indigo. Science 222, 167-169.

Franklin, F. C. H. \& Williams, P. A. (1980). Construction of a partial diploid for the degradation pathway encoded by the TOL plasmid (pWW0) from Pseudomonas putida $\mathrm{mt}-2$ : evidence for the positive nature of the regulation by the $x y l R$ gene. Molecular and General Genetics 177, 321-328.

GRINTER, N. J. (1983). A broad-host range cloning vector transposable to various replicons. Gene 21 , 133-143.

Grund, A. D. \& Gunsalus, I. C. (1983). Cloning of genes for naphthalene metabolism in Pseudomonas putida. Journal of Bacteriology 156, 89-94.

Guerry, P., LeBlanc, D. J. \& Falkow, S. (1973). General method for the isolation of plasmid deoxyribonucleic acid. Journal of Bacteriology 116, 1064 1066.

Holmes, D. S. \& Quigley, N. (1981). A rapid boiling method for preparation of bacterial plasmids. Analytical Biochemistry 114, 193-197.

Keil, H. \& Williams, P. A. (1985). A new class of TOL plasmid deletion mutants in Pseudomonas putida MT15 and their reversion by tandem gene amplification. Journal of General Microbiology 131, 1023-1033.

KeIL, H., Lebens, M. R. \& Williams, P. A. (1985a).
TOL plasmid pWW15 contains two non-homologous catechol 2,3-oxygenase genes independently regulated. Journal of Bacteriology 163, 248-255.

Keil, H., Keil, S., Pickup, R. W. \& Williams, P. A. $(1985 b)$. The complete meta pathway operon of the toluene/xylene catabolic pathway cloned from TOL plasmid pWW53. Journal of Bacteriology 164, 887895.

McCormick, M., Wishart, W., OHTSubo, H., HefFron, F. \& OHtsubo, E. (1981). Plasmid cointegrates and their resolution mediated by transposon Tn3 mutants. Gene 15, 103-118.

MCDonnell, M. W., Simon, M. N. \& Studier, F. W. (1977). Analysis of restriction fragments of T7 DNA and determination of molecular weights by electrophoresis in neutral and alkaline gels. Journal of Molecular Biology 110, 119-146.

Meulien, P. \& BRODA, P. (1982). Identification of chromosomally integrated TOL DNA in cured derivatives of Pseudomonas putida PaWl. Journal of Bacteriology 152, 911-914.

Murray, K., Duggleby, C. J., Sala-Trepat, J. M. \& Williams, P. A. (1972). The metabolism of benzoate and methylbenzoates via the meta-cleavage pathway by Pseudomonas arvilla mt-2. European Journal of Biochemistry 28, 301-310.

Nakazawa, T., Inouye, S. \& Nakazawa, A. (1980). Physical and functional mapping of RP4-TOL plasmid recombinants: analysis of insertion and deletion mutants. Journal of Bacteriology 144, 222231.

Shamsuzzaman, K. M. \& Barnsley, E. A. (1974). The regulation of naphthalene oxygenase in Pseudomonads. Journal of General Microbiology 83, 165170.

Southern, E. M. (1975). Detection of specific sequences among DNA fragments separated by gel electrophoresis. Journal of Molecular Biology 98, 503-571.

Wheatcroft, R. \& Williams, P. A. (1981). Rapid methods for the study of both stable and unstable plasmids in Pseudomonas. Journal of General Microbiology 124, 433-437.

Williams, P. A., Catterall, F. A. \& Murray, K. (1975). Metabolism of naphthalene, salicylate and benzoate by Pseudomonas $P_{G}$ : regulation of tangential pathways. Journal of Bacteriology 124, 679-685.

Williams, P. A., Cane, P. A., Jeenes, D. J. \& Pickup, R. W. (1983). Correlation between spontaneous phenotypic changes in Pseudomonas strains with changes in the structure of catabolic plasmids: experience with TOL plasmids. In Basic Biology of New Developments in Biotechnology, pp. 519-552. Edited by A. Hollaender, A. I. Laskin \& P. Rogers. New York and London: Plenum Press.

Worsey, M. J., Franklin, F. C. H. \& Williams, P. A (1978). Regulation of the degradative pathway enzymes coded for by the TOL plasmid (pWW0) from Pseudomonas putida mt-2. Journal of Bacteriology 134, 757-764.

Yen, M. \& Gunsalus, I. C. (1982). Plasmid gene organisation: naphthalene/salicylate oxidation. Proceedings of the National Academy of Sciences of the United States of America 79, 874-878.

Yen, M. \& GunSalus, I. C. (1985). Regulation of naphthalene catabolic genes of plasmid NAH7. Journal of Bacteriology 162, 1008-1013. 